\title{
SELF-REPORTED HABITUAL PRACTICES AND PERCEPTIONS OF YOUNG DRIVERS IN SRI LANKA
}

\author{
N Amarasingha ${ }^{a *}$ and $H$ M M Firdhaws ${ }^{b}$ \\ a,b Department of Civil Engineering, Sri Lanka Institute of Information \\ Technology, New Kandy Road, Malabe, Sri Lanka \\ * Corresponding author E-mail address: niranga.a@sliit.lk
}

\begin{abstract}
Crashes on the road have become a significant socio-economic problem. Younger generations, who have lesser experience in driving, are at greater risks offacing road accidents. It is therefore important to identify driving practices and perceptions of young and inexperienced drivers at an early phase of exposure so that factors that improve safe driving can be identified.
\end{abstract}

This study analysed 400 young and inexperienced drivers' self-reported habitual practices and perceptions based on a questionnaire survey. The questionnaire focused on supervision of early driving, limitation made by parents, accident and traffic offenses by these youngsters as drivers as well as other habitual driving practices. Analyses were done using reliability statistics, inter-item correlation, likelihood ratio tests, and parameter estimates. The highest inter-item correlation value was 0.467 for the pair of overtaking vehicles in restricted areas and taking the chance to speed and run a yellow light when it is about to change to red. Driving after alcohol consumption, mobile phone usage, taking an illegal U-turn at restricted areas, non-use of signals when changing lanes and overtaking a slow driver from the left side were influenced non-use of seat-belts by young drivers. These habitual practices while driving highlighted the importance of early intervention to improve road safety.

In conclusion, there is always one or more habitual driving practices that have affect the other driving habits of a young driver.

Keywords: Inexperienced Drivers, Driver Perception, Driving Practices, Road Safety, Sri Lanka 


\section{INTRODUCTION}

One of the problems that people face and hear every day are crashes on the road. When the crash rates or traffic violations are considered, the younger generation is in more risk as they have the least experience in driving. A study done in the State of Qatar showed drivers aged 18 years or less frequently committed driving violations and caused accidents, followed by the drivers aged 18 to 25 years [1]. Young drivers start to drive with more caution but overestimate their skill and start multi-tasking with mobile phones, eating and talking with other passengers while driving: all sources of distraction [2]. Also, the most common reason which leads to high crash rates is speeding [3]. Young people drive faster when they are with peer passengers to show confidence and skill [4]. When there is an aggressive behaviour involved while driving, there are higher chances of drivers taking risks. Aggressive behaviour occurs when there is less attention to road safety, pressure from friends, and less commitment and communication shared by the person who monitors the young driver's behaviour while $\mathrm{s} / \mathrm{he}$ is driving [5]. The roles of parents and friends are important in shaping good driving behaviour among young drivers. Since young drivers have less experience, they may easily get involved in a traffic crash [1]. These highlight the need for a better driver education, a strict licensing process, and proper guidance for young inexperienced drivers.

As per authors' knowledge, a proper study has not been conducted in Sri Lanka to investigate the young inexperienced drivers' crash risk, characteristics, or driving behaviour. Therefore, the objective of this study was to identify the negative habitual practices while driving among young inexperienced drivers in Sri Lanka.

\section{LITERATURE REVIEW}

The study began by reviewing similar studies in the past that identify risk factors among young drivers.

Shaaban et al. studied the cell phone usage habits of young drivers in Qatar [6]. This covered awareness among those drivers about their dangerous habits and the factors influencing their habits using a self-reported questionnaire. The survey was done for a sample of 403 of young drivers of the age 18 to 25 years old who had valid driving licenses. The analysis was done using a Structural Equation Modeling technique. The results showed that holding public campaigns may decrease cell phone usage while driving. Young drivers involved in a crash in the past tend to use their cell phones less than those who never had a cell phone related crash. The driving experience and the duration where the driver can be safe by keeping his eyes away from the road when driving had a significant effect on cell phone usage. In this study most of the participants (90.8\%) agreed that they used their cell phone while driving. The participants were asked about their first action when they received a phone call. Most 
of the participants $(73.2 \%)$ mentioned that they usually answer the phone and continue driving, while $11.2 \%$ mentioned that they stop the vehicle first then answer the phone, and 9\% stated that they answer first then stop the vehicle. When participants were questioned about how talking over the phone affected their driving, $20.5 \%$ answered that talking while driving had no effect on driving performance. Remaining participants stated that their driving was affected in many ways, like slower driving and drifting in and out of lanes. Based on these results, it was suggested to provide road safety campaigns to educate the young drivers on the risks associated with calling, answering, texting and browsing while driving.

Soliman et al. examined the young drivers' behaviour using a Driving Behaviour Questionnaire (DBQ) across different age groups considering different demographics such as gender, car type, seatbelt use, occupation, and education level in the State of Qatar [1]. The questionnaire was distributed to participants who were divided into five age groups. The DBQ was used to measure the various driving behaviour using a six-point scale. Results showed vast differences between the five age groups. The age group that most frequently committed driving violations were those aged 18 years or less, and it was followed by those who were aged 18 to 25 years. Also, individuals who did not wear seatbelts reported more driving violations; results showed that $36.6 \%$ of the participants did not use seatbelts while driving. Those with low or medium levels of education reported that they were more likely to commit driving violations than those who were well educated. The results also showed that the female drivers drove safer than male drivers and reported significantly fewer driving violations. Also, female drivers with higher levels of education wore seatbelts more often and committed driving violations much less frequently than male drivers. Moreover, the young male drivers aged less than 25 years who had low levels of education had the highest frequency of committing driving violations. This study highlighted the need for a better driver education and licensing process in Qatar.

Alreesi et al. developed a valid, modified and reliable measurement tool that can be used by young drivers in Oman [7]. A self-reported questionnaire was developed to find risky driving behaviour among a sample of Omani inexperienced drivers aged between 17 and 25 years. There were 1,319 young drivers who completed the questionnaire of which $27.1 \%$ were female. An exploratory factor analysis was used to find the best factor structure for the 40-items behaviour scale that was selected from the questionnaire. This factor analysis revealed seven dimensions for the behaviour which explained $49.28 \%$ of the variance in the behavioural scale of the young drivers. Those factors were transient violations, speeding, mood driving, fatigue driving, distracted driving, seatbelt usage and close following. In the composite behaviour an excellent internal consistency $(\mathrm{a}=0.939)$ was shown where the transient violations showed the highest internal consistency $(a=0.927)$ and the lowest internal consistency $(\mathrm{a}=0.700)$ was shown for close following. Logistic 
models between all seven behavioural dimensions and crash involvement adjusted for drivers' characteristics were conducted and the results showed that moody, fatigued and distracted driving were reasons for crash incidence among young drivers. The composite scales showed a good internal consistency for the crash involvement by the drivers. Although it was suggested that the subscale factors required further investigation on reliability, the strongest predictor for crash involvement was shown by the distraction subscale factor.

Ben-Ari et al. compared young drivers from Queensland (Australia) and Israel and investigated the contributors of the risky driving behaviour of young drivers [8]. The aim was to examine the relationship between the willingness to take risks while driving and the young driver's perceptions. For this study young drivers aged 17- 22 from Queensland $(n=164)$ and Israel $(n=161)$ participated in a set of reliable selfreported questionnaires. The Bayesian estimation of the linear regression model was used for the analysis of this study. The results indicated that the Israeli young drivers regarded their parents as providing more role modelling and good communication, messages and feedback than those in Queensland. The young drivers from Queensland reported less commitment to road safety in their families. Similarly, young Israeli drivers associated less cost to driving with friends and at the same time took in more communication and experience from their friends than the young drivers from Queensland. In both the samples, higher intention to take risks involved a higher tendency towards aggressive behaviour, less family orientation towards road safety, greater friends' pressure and less commitment by friends while these young people are driving. Women from this survey reported much less willingness to take risks than young male drivers. The young drivers with divorced or separated parents answered higher will to drive more recklessly than those young drivers from intact families. Little variation existed with specific factors which contributed differently for both the Queensland and the Israel sample. The findings from this study from two different samples from two different countries yielded quite similar results. An important finding was that the central roles of parents and friends must be taken into consideration in every attempt to reduce the rates of risky driving by young drivers.

Scott-Parker et al. studied the Graduated Driver Licensing (GDL) systems which was introduced in 2007 at Queensland, Australia [9]. The GDL system was designed facilitating young drivers get experience in low risk environments and situations. This system has three stages the young drivers need to pass: namely learner's permit, provisional license, and full driver's license. They start off by obtaining the learner's permit, followed by a provisional license which is also known as the intermediate license and finally the full driver's license. All these three stages of this system had their own limitations and restrictions. Initially there were restrictions on driving in night-time and expressways but those restrictions were lifted once the full driver's license was obtained after several testing. For this study there were 1,032 young 
drivers: 609 female and 423 male aged 17 to 19 years. They volunteered and participated in a 30 minute survey as the learner drivers. After six months another 30 minutes survey was done for the intermediate license stage. The non-parametric Wilcoxon signed-rank tests and matched-pair analysis, were used for the nonnormally distributed Likert scale questions. The Cronbach's alpha was also used to measure the internal consistency of data. Participants reported on driving experience, difficulties, and the offenses they committed like taking an illegal U-turn, using mobile phones, and crashing the vehicle while reversing. Most of the young drivers in this study reported that they complied with the GDL requirements and the general rules that need to be followed on the road. This study showed that speeding should be targeted since speed limit was a rule the young drivers obeyed less.

Young inexperienced drivers' risk has been identified using the questionnaire surveys effectively in many countries in the world as shown in above literature studies. In particular Sri Lanka as a developing country has limited crash data which developed countries use to identify crash risk. Therefore, in this study the young inexperienced drivers' behaviour on the road and habitual practices were investigated through a questionnaire survey.

\section{OBTAINING DRIVER LICENCE IN SRI LANKA}

In Sri Lanka there are two licence categories: light vehicle licence and heavy vehicle licence which is an extension of the light vehicle licence. Under the light vehicle category, the licence classes A1, A, B1, B and G1 and under the heavy vehicle, licence classes C1, C, CE, D1, D, DE, G and J are issued [10]. Table 1 shows vehicles under each licence class in Sri Lanka according to the Section 122 of Motor Traffic Act amended by Act no.08 of 2009.

According to guidelines provided by the Motor Traffic Act amended by Act No.08 of 2009 to obtain a driver license, a person can register and sit for the written test for light vehicle category (classes A1, A, B1, B) when 17 years of age has been completed [10]. Prior to filling the application for driving license, an aptitude medical certificate has to be obtained from any of the National Transport Medical Institution. The institute provide medical services by examining and issuing certificates of physical and mental fitness to drivers of all types of vehicles. Once medical test is completed, a written test consisting of 40 multiple choice questions has to be done. In this test the knowledge on the road signs and traffic rules are assessed. Once the written test is passed, a learners' permit is issued for up to a maximum of 18 months. Holder of learners' permit can practice driving under supervision of licensed driver along with "L" board fitted to the front and rear of the vehicle [10]. A person who completes 18 years of age and a minimum of three months of experience under learners' permit can face the road test [10]. In road test, the general driving ability is 
checked including fastening the seat belt before starting the vehicle, pulling over at the side of the road, reversing the vehicle, parallel parking at the side of the road. It is compulsory to face the road test and pass it to obtain the driving license. Table 2 gives the number of tests conducted all over Sri Lanka from January 2016 to December 2017.

Table 1: Vehicles under Different Licence Classes

\begin{tabular}{|c|c|}
\hline $\begin{array}{l}\text { License } \\
\text { Class } \\
\end{array}$ & Description \\
\hline A1 & Light motorcycles of which the engine capacity is less than $100 \mathrm{CC}$ \\
\hline $\mathbf{A}$ & Motorcycles of which engine capacity is more than $100 \mathrm{CC}$ \\
\hline B1 & $\begin{array}{l}\text { Motor tricycle or van of which the tare weight is not more than } 500 \mathrm{~kg} \text { and gross } \\
\text { vehicle weight is not more than } 1000 \mathrm{~kg}\end{array}$ \\
\hline B & $\begin{array}{l}\text { Dual purpose motor vehicle of which the gross vehicle weight is not more than } \\
3500 \mathrm{~kg} \text { and the maximum seating capacity including the driver's seat is } 9 \text { seats }\end{array}$ \\
\hline C1 & $\begin{array}{l}\text { Motor lorries of which the gross vehicle weight is more than } 3500 \mathrm{~kg} \text { and less } \\
\text { than } 17000 \mathrm{~kg} \text {. Motor vehicles of this class also includes motor hearses and } \\
\text { ambulances }\end{array}$ \\
\hline $\mathbf{C}$ & $\begin{array}{l}\text { Motor lorries of which the gross vehicle weight is more than } 1700 \mathrm{~kg} \text {. This class } \\
\text { of vehicles can be combined with a trailer which has a maximum tare weight of } \\
750 \mathrm{~kg}\end{array}$ \\
\hline CE & $\begin{array}{l}\text { Heavy motor lorries of which the gross vehicle weight is less than } 3500 \mathrm{~kg} \text {. } \\
\text { These vehicles are a combination of a motor lorry and trailers of which the tare } \\
\text { weight of a trailer is more than } 750 \mathrm{~kg}\end{array}$ \\
\hline D1 & $\begin{array}{l}\text { Light Motor Coach- These motor vehicles used for the carriage of people and } \\
\text { having a seating capacity more than } 9 \text { seats and less than } 33 \text { seats including the } \\
\text { driver's seat. This class of motor vehicle can be combined with a trailer having } \\
\text { a maximum tare weigh of } 750 \mathrm{~kg}\end{array}$ \\
\hline D & $\begin{array}{l}\text { These are motor coaches where the maximum seating capacity is } 33 \text { seats } \\
\text { including the driver's seat. This class of motor vehicle can be combined with a } \\
\text { trailer having a maximum tare weigh of } 750 \mathrm{~kg}\end{array}$ \\
\hline DE & $\begin{array}{l}\text { These are heavy motor coaches having a seating capacity of } 33 \text { seats including } \\
\text { the driver's seat. This has a combination of two motor coaches or a combination } \\
\text { of a motor coach and a trailer having a tare weight more than } 750 \mathrm{~kg}\end{array}$ \\
\hline G1 & Hand tractors - These are two-wheel tractors with a trailer \\
\hline $\mathbf{G}$ & Land vehicles - These are agricultural land vehicles with or without a trailer \\
\hline $\mathbf{J}$ & $\begin{array}{l}\text { These are special purpose vehicles, which are used for construction, loading \& } \\
\text { unloading and they are equipped with construction equipment and equipment } \\
\text { for loading and unloading goods }\end{array}$ \\
\hline
\end{tabular}


Table 2: Written and practical test attempts in Sri Lanka from 2016 to 2017

\begin{tabular}{|c|c|c|c|c|c|}
\hline \multirow{2}{*}{$\begin{array}{l}\text { Age } \\
\text { (years) }\end{array}$} & \multirow{2}{*}{ Description } & \multicolumn{2}{|l|}{ Written Test } & \multicolumn{2}{|l|}{ Practical test } \\
\hline & & Male & Female & Male & Female \\
\hline$<17$ & Number & 0 & 0 & 0 & 0 \\
\hline \multirow{2}{*}{$17-19$} & Number & 79,197 & 10,612 & 98,647 & 8,160 \\
\hline & Percentage $\%$ & 23.1 & 3.1 & 23 & 1.9 \\
\hline \multirow{2}{*}{$20-22$} & Number & 35,972 & 10,749 & 41,263 & 11,226 \\
\hline & Percentage $\%$ & 10.5 & 3.1 & 9.6 & 2.6 \\
\hline \multirow{2}{*}{$23-25$} & Number & 22,863 & 9,514 & 27,253 & 10,106 \\
\hline & Percentage $\%$ & 6.7 & 2.8 & 6.4 & 2.4 \\
\hline \multirow{2}{*}{$26-28$} & Number & 8,856 & 4,502 & 11,384 & 4,958 \\
\hline & Percentage $\%$ & 2.6 & 1.3 & 2.7 & 1.2 \\
\hline \multirow{2}{*}{$>28$} & Number & 96,865 & 63,649 & 141,267 & 74,787 \\
\hline & Percentage $\%$ & 28.3 & 18.6 & 33 & 17.4 \\
\hline \multirow{2}{*}{ Total } & Number & 243,753 & 99,026 & 319,814 & 109,237 \\
\hline & Percentage $\%$ & 71.1 & 28.9 & 74.5 & 25.5 \\
\hline
\end{tabular}

Source: Department of Motor Traffic, 2018

Heavy vehicles driving licenses are the extension of the light vehicle driving licences. The person applying for a heavy vehicle driving licence should be a holder of a light vehicle driving licence of class B or B1 at least two years prior to the date of application [10]. To obtain a licence for light motor bus and light motor category the minimum height of the person should be four feet 10 inches. A minimum height of five feet is required to obtain a license for motor bus and motor lorry category [10].

As shown in Table 2, almost $25 \%$ of people who attempted the practical test were in 17- 19 years age category while about $50 \%$ were aged more than 28 years. The total vehicle population in Sri Lanka in 2010 and 2016 is 3,954,311 and 6,334,992 respectively [11]. There is an increase of 2.3 million vehicles in Sri Lanka within six years. When there is a large increase of vehicle population, attention must be paid to the driving behaviour of people which is a main safety concern for both the drivers and pedestrians. The willingness of the younger age group to obtain driving license highlights the need to focus on driving behaviour of young people. This study is significant as it involves the findings of young drivers and their habitual practices. This is important because finding out the factors that affect a young person's driving behaviour can help in early intervention and prevention of those factors and reckless driving. 


\section{METHODOLOGY}

\subsection{Development of questionnaire and sample size}

This research study investigates the habitual practices of the young drivers. Data were collected using a questionnaire form consisting of several questions related to risks involving young drivers. The form also contained questions related to the social economic details of the driver, the type of vehicles they drive, their license categories, the speed at which they drive and some questions related to the habitual practices of the drivers which leads to accidents. The risky aspects and habitual practices were identified by reviewing the previous studies and verified though a pilot survey. The sample size calculation was done according to Equation (1) [12].

$$
n=\frac{\left(Z a \gamma_{2} \times \sigma\right)^{2}}{e^{2}}
$$

where, $n=$ sample size, $Z=$ the critical value at $(\alpha / 2) \%$ significance level, $\sigma=$ standard deviation, and $\mathrm{e}=$ significance interval.

The minimum sample was obtained by assuming a 95\% confidence level $(\mathrm{Z}=1.96)$ and a $5 \%$ significance interval $(e=0.05)$. To obtain the minimum sample size a standard deviation of 50\% was assumed [6]. This resulted in a minimum sample size of 385. A total of 400 survey forms were printed and distributed. Out of them, 278 were answered by male respondents and 122 were answered by female respondents. The majority of the people who answered the questionnaire was of the age group 19 to 24 which consisted of $83.8 \%$ of the total sample size. About $6 \%$ respondents were age below 19 years and the rest of $10.2 \%$ were age above 24 years. Out of the 400 participants 302 had full license, 28 had just the learner's permit while 70 participants had not taken driving license. All the above people had been exposed to driving at least for 6 months. Only 172 participants out of 400 had driven under someone's supervision who owns a driving license. From the total sample, 230 participants who admitted that their parents has imposed driving limitations, said it was always about speeding where their parents always asked them not to speed. Regarding the involvement in accidents, only 68 participants had been involved in an accident. It was highlighted when it came to traffic offenses committed by them, the highest number for getting pulled over by the police was due to overtaking in restricted areas which was 75 and followed by speeding which was 46 . The number of offences for parking in restricted areas was 32, driving without a valid licence 30 and followed by not wearing seatbelt was 16 . The least response recorded was for crossing the signal before it turned green which was 12 .

\subsection{Survey locations}

The printed questionnaires were distributed at Diyatha-Uyana in Battaramulla, SLIIT campus in Malabe, Viharamahadevi Park, and in Peradeniya garden. In these 
locations, young men and women gathered and therefore easily could be found the young and inexperienced drivers. They were seated in these locations and willing to fill the questionnaire forms by themselves. The questionnaire forms were not just given to those who had driving license but also for those who had learner's permit and for those who have driven vehicles without obtaining driving license.

\subsection{Cronbach's Alpha Reliability Test}

To get this information from the respondents, a 5-unit likert scale from 1 to 5 was used where; $1=$ never, $2=$ occasionally, $3=$ sometimes, $4=$ most of the time and $5=$ always [5]. This helps in avoiding difficult survey questions like open-ended and fillin-the-blank questions. Cronbach's Alpha reliability test was used to measure the internal consistency between items in a scale to study the correlation of every item in the likert scale with every other item [13]. This is expressed as a number between 0 and 1 . The acceptable values of alpha is from 0.70 to 0.95 and if the value is less than 0.70 considered as questionable [13]. The internal consistency was found before a research to ensure validity. If the items that are subjected to test are well correlated to each other, then the value of alpha is higher. However, if the alpha value is high it does not always mean that it has a higher degree of internal consistency since alpha values can also be affected by the length of the test. The alpha value is also sensitive to the number of tests. The value of alpha can get short if the test length is short. Poor inter-relation between items and inadequate number of questions could also lead to low value of alpha. If the value of alpha is greater than 0.95 , it may suggest redundancies and show that the test length needs to be shortened [13].

\subsection{Multinomial Logistic Regression}

Multinomial Logistic Regression analysis is a predictive analysis and is used for explaining the relationship between a nominal or ordinal dependent variable and one or more independent variables [14]. When the dependent variable is qualitative and if it has more than two possible answers or categories, then multinomial logistic regression could be used to estimate the probability of occurrences for each of the alternatives. The Likert scale used in this study comes under the ordinal variable set which has a 5 point scale namely: never, occasionally, sometimes, most of the time and always.

The model fitting information of multinomial logistic regression contains a likelihood ratio chi- squared test, comparing the full model against a null model. The full model contains all the predictors whereas the null model will not have predictors. The threshold value to consider an overall model as fit or not is the 5\% significance level (p- value) [14]. If the significant value is less than 0.05 , the null hypothesis (intercept only model) is rejected. This means that the final model is more significant than the null model and the final model is considered as fit. 


\section{RESULTS}

The responses for the all the self-reported negative habitual practices are tabulated in Table 3.

Table 3: Self-reported Driving Habits of Young Drivers

\begin{tabular}{|c|c|c|c|c|c|c|}
\hline Habitual driving practices & $\underbrace{\widehat{d}}_{\dot{d}}$ & 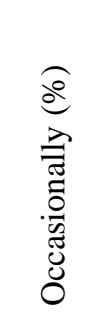 & 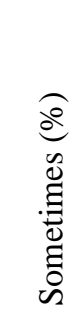 & 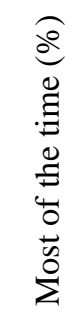 & $\begin{array}{l}\underset{0}{0} \\
\frac{n}{2} \\
\frac{3}{2}\end{array}$ & 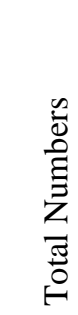 \\
\hline Over speeding & 96.5 & 1.0 & 2.0 & 0.5 & 0.0 & 400 \\
\hline Driving after alcohol consumption & 95.3 & 2.3 & 2.5 & 0.0 & 0.0 & 400 \\
\hline Mobile phone usage & 56.5 & 20.5 & 18.0 & 1.0 & 4.0 & 400 \\
\hline Taken an illegal U-turn at restricted areas & 53.8 & 27.3 & 14.3 & 3.0 & 1.8 & 400 \\
\hline $\begin{array}{l}\text { Indicate signals when you are changing } \\
\text { lanes }\end{array}$ & 4.3 & 1.5 & 6.5 & 23.3 & 64.5 & 400 \\
\hline $\begin{array}{l}\text { Wearing seat belts even if it was only for a } \\
\text { short trip }\end{array}$ & 8.8 & 4.3 & 13.0 & 14.0 & 60.0 & 400 \\
\hline $\begin{array}{l}\text { Carrying more passengers than that could } \\
\text { legally fit in your vehicle }\end{array}$ & 45.3 & 19.0 & 23.5 & 7.5 & 4.8 & 400 \\
\hline $\begin{array}{l}\text { Taking chance to try to speed and run a } \\
\text { yellow light when it is about to change to red }\end{array}$ & 49.0 & 23.5 & 21.3 & 4.8 & 1.5 & 400 \\
\hline $\begin{array}{l}\text { Overtake vehicles in restricted areas. (ex: } \\
\text { double lined road area and curvy roads) }\end{array}$ & 56.5 & 22.5 & 19.3 & 1.8 & 0.0 & 400 \\
\hline Overtaking a slow driver from the left side & 56.8 & 16.5 & 15.0 & 7.0 & 4.8 & 400 \\
\hline
\end{tabular}

\subsection{Reliability Statistics}

To apply Cronbach's Alpha reliability test for a set of items, all the Likert scaled items were phrased in negative order. Table 4 gives the average correlation among the 10 items that were questioned. The Cronbach's alpha value 0.705 suggests that the average correlation among the ten items, that is in the questionnaire, indicate marginally an acceptable reliability since the value is just greater than 0.70 [15]. This value is a good indication about the average correlation among the Likert scale questions from the questionnaire. 
Table 4: Reliability Statistics

\begin{tabular}{|c|c|c|}
\hline Cronbach's Alpha & $\begin{array}{c}\text { Cronbach's Alpha Based on } \\
\text { Standardized Items }\end{array}$ & Number of Items \\
\hline 0.705 & 0.705 & 10 \\
\hline
\end{tabular}

\subsection{Inter-Item Correlation}

Along with the Cronbach's Alpha values, the internal consistency among items was tested using the inter-item correlation measures which are also part of reliability tests.

Table 5: Inter-Item Correlation Matrix

\begin{tabular}{|c|c|c|c|c|c|c|c|c|c|c|}
\hline & $\begin{array}{l}\stackrel{\infty}{\Xi} \\
\stackrel{n}{0} \\
\stackrel{\Xi}{5}\end{array}$ & 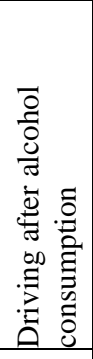 & $\begin{array}{l}0 \\
00 \\
0 \\
0 \\
0 \\
0 \\
0 \\
0 \\
2 \\
0 \\
00 \\
0 \\
\Sigma\end{array}$ & 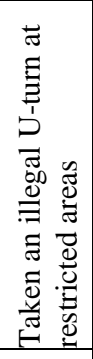 & 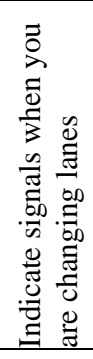 & 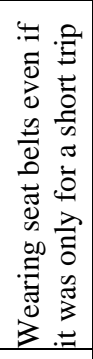 & 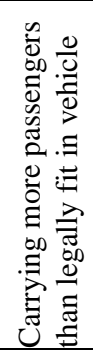 & 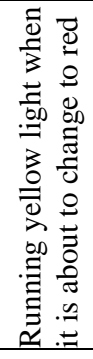 & 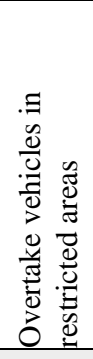 & 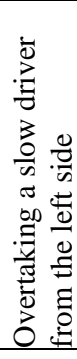 \\
\hline Smoking & 1 & 0.245 & 0.208 & 0.047 & 0.098 & 0.038 & 0.018 & 0.245 & 0.309 & 0.248 \\
\hline $\begin{array}{l}\text { Driving after } \\
\text { alcohol } \\
\text { consumption }\end{array}$ & 0.245 & 1 & 0.26 & 0.126 & 0.246 & 0.071 & 0.097 & 0.094 & 0.154 & 0.129 \\
\hline $\begin{array}{l}\text { Mobile phone } \\
\text { usage }\end{array}$ & 0.208 & 0.26 & 1 & 0.311 & 0.303 & 0.321 & 0.237 & 0.176 & 0.213 & 0.269 \\
\hline $\begin{array}{l}\text { Taken an illegal } \\
\text { U-turn at } \\
\text { restricted areas }\end{array}$ & 0.047 & 0.126 & 0.311 & 1 & 0.144 & 0.283 & 0.131 & 0.208 & 0.363 & 0.177 \\
\hline $\begin{array}{l}\text { Indicate signals } \\
\text { when you are } \\
\text { changing lanes }\end{array}$ & 0.098 & 0.246 & 0.303 & 0.144 & 1 & 0.432 & 0.102 & 0.042 & 0.204 & 0.19 \\
\hline $\begin{array}{l}\text { Wearing seat belts } \\
\text { even if it was only } \\
\text { for a short trip }\end{array}$ & 0.038 & 0.071 & 0.321 & 0.283 & 0.432 & 1 & 0.187 & 0.104 & 0.221 & 0.317 \\
\hline $\begin{array}{l}\text { Carrying more } \\
\text { passengers than } \\
\text { legally fit in } \\
\text { vehicle }\end{array}$ & 0.018 & 0.097 & 0.237 & 0.131 & 0.102 & 0.187 & 1 & 0.16 & 0.035 & 0.256 \\
\hline $\begin{array}{l}\text { Running yellow } \\
\text { light when it is } \\
\text { about to change to } \\
\text { red }\end{array}$ & 0.245 & 0.094 & 0.176 & 0.208 & 0.042 & 0.104 & 0.16 & 1 & 0.467 & 0.308 \\
\hline $\begin{array}{l}\text { Overtake vehicles } \\
\text { in restricted areas. }\end{array}$ & 0.309 & 0.154 & 0.213 & 0.363 & 0.204 & 0.221 & 0.035 & 0.467 & 1 & 0.309 \\
\hline $\begin{array}{l}\text { Overtaking a slow } \\
\text { driver from the } \\
\text { left side }\end{array}$ & 0.248 & 0.129 & 0.269 & 0.177 & 0.190 & 0.317 & 0.256 & 0.308 & 0.309 & 1 \\
\hline Note: & & \multicolumn{9}{|c|}{ Coloured box indicates the values more than 0.300 (threshold value) } \\
\hline
\end{tabular}


Inter-Item Correlation is defined as the correlation with every item considered in the scale with each other time. The larger the value and closer to 1, then the relationship between the response is stronger. Table 5 gives the correlation matrix, in which every value is significant at $95 \%$ confidence level. Also, every value above the diagonal 1 's and every value below it are the same. The optimal value for the mean inter-item correlation ranges from 0.2 to 0.4 [15].

'Overtaking vehicles in restricted areas' and 'taking chance to speed up and run a yellow light when it is about to change to red' are the two items that had the highest inter- item correlation value of 0.467 . This higher value indicated that young drivers who overtake vehicles in restricted areas are also more likely to speed up and running yellow light when it is about to change to red. The second highest inter item correlation value obtained is 0.432 and the third highest inter item correlation value obtained is 0.363 . These values indicate how each item is correlated with each other. Out of the 45 available inter- item correlation values, 24 of those inter- item correlation values are greater than 0.2 which suggests that those 24 pair of items have an influence on each other where, when one of the items in a particular pair occurs then there is more chance for the second item of the same pair to occur along with it.

The internal consistency among the Likert scale items from Cronbach's alpha test is 0.705. This value is a good indication about the average correlation among the Likert scale questions from the questionnaire. There are results of 45 available inter- item correlation values. The highest inter-item correlation value 0.467 is obtained for the pair; overtaking vehicles in restricted areas and taking chance to try to speed and run a yellow light when it is about to change to red.

\subsection{Likelihood Ratio Tests}

For the multinomial logistic regression, the variable 'wearing seat belts even if it is for a short trip' is selected as the dependent variable among the Likert scale set of questions. If young drivers use the seat belt they assume low risk as effectiveness of seat belt reducing crash injuries are well known [16]. However, when the inter-item correlations values are considered, 'overtake vehicles in restricted areas' has four variables above the threshold value (0.300) whereas variable 'wearing seat belts even if it was for a short trip' has three variables. Statistically, it is recommended to select the dependent variable as the variable which has high correlation with many other variables. The other remaining habitual practices among young drivers are selected as the independent variables.

The model was used to analyse how these habitual practices have had an effect on the positive action of a young driver wearing seat belts: in other words, reducing the crash injuries. The significant likelihood ratio values of the habitual practices among the young drivers are shown in Table 6. 
Table 6: Likelihood ratio significant values from Multinomial logistic regression

\begin{tabular}{|l|c|c|c|}
\hline Effect & Chi-Square & df & Sig. \\
\hline $\begin{array}{l}\text { Wearing seat belts even if it was for a short trip } \\
\text { (Dependent variable) }\end{array}$ & - & - & - \\
\hline Smoking & 3.674 & 4 & 0.452 \\
\hline Driving after alcohol consumption & 9.995 & 4 & 0.041 \\
\hline Mobile phone usage & 15.250 & 4 & 0.004 \\
\hline Taken an illegal U-turn at restricted areas & 16.200 & 4 & 0.003 \\
\hline Indicate signals when you are changing lanes & 47.580 & 4 & 0.000 \\
\hline $\begin{array}{l}\text { Carrying more passengers than that could legally fit in } \\
\text { your vehicle }\end{array}$ & 5.910 & 4 & 0.206 \\
\hline $\begin{array}{l}\text { Taking chance to try to speed and run a yellow light } \\
\text { when it is about to change to red }\end{array}$ & 7.210 & 4 & 0.125 \\
\hline $\begin{array}{l}\text { Overtake vehicles in restricted areas. (ex: double lined } \\
\text { road area and curvy roads) }\end{array}$ & 5.640 & 4 & 0.227 \\
\hline Overtaking a slow driver from the left side & 22.830 & 4 & 0.000 \\
\hline
\end{tabular}

Using the conventional $\alpha=0.05$, it can be observed that driving after alcohol consumption, mobile phone usage, taking an illegal U-turn at restricted areas, not indicating signals when you are changing lanes, and overtaking a slow driver from the left side are the significant variables. These five independent variables have significant impact on the seat belt not wearing of young drivers indicating high injury risks. A similar study in Australia identified several factors including these four out of five variables were more frequently reported by young novice drivers than provisional drivers [9]. However, overtaking a slow driver from wrong side has not been investigated or reported before. Driving after alcohol consumption is identified as a factor which increases the severity of injury which can be supported with the previous literature [16]. Mobile phone usage is also identified as a primary distraction factor increasing the injury risk of young drivers in several previous studies in different countries [1, 6, 7, 9, 16, and 17].

\subsection{Parameter Estimates}

The results of parameter estimates provide information about each option in the Likert scale against the reference category option (never) of the dependent variable: wearing seat belts even if it was for a short trip. There are 36 parameter estimates values of which 15 of them have their significant values less than 0.05 as shown in Table 7 . 
Table 7: Parameter Estimates of wearing seat belts with reference as 'Never'

\begin{tabular}{|c|c|c|c|c|c|}
\hline \multicolumn{2}{|c|}{$\begin{array}{l}\text { Wearing seat belts even if it was only for a } \\
\text { short trip }\end{array}$} & \multirow{2}{*}{$\begin{array}{c}\beta \\
0.532\end{array}$} & \multirow{2}{*}{$\begin{array}{l}\text { Std. } \\
\text { Error } \\
0.186\end{array}$} & \multirow{2}{*}{$\begin{array}{l}\text { Sig. } \\
\mathbf{0 . 0 0 4}\end{array}$} & \multirow{2}{*}{$\begin{array}{r}\operatorname{Exp}(\beta) \\
1.703\end{array}$} \\
\hline Occasionally & $\begin{array}{l}\text { Taken an illegal U-turn at } \\
\text { restricted areas }\end{array}$ & & & & \\
\hline & $\begin{array}{l}\text { Taking chance to try to } \\
\text { speed and run a yellow light } \\
\text { when it is about to change to } \\
\text { red }\end{array}$ & 0.341 & 0.167 & 0.042 & 1.406 \\
\hline & $\begin{array}{l}\text { Overtaking a slow driver } \\
\text { from the left side }\end{array}$ & 0.49 & 0.148 & 0.001 & 1.633 \\
\hline \multirow[t]{3}{*}{ Sometimes } & $\begin{array}{l}\text { Taken an illegal U-turn at } \\
\text { restricted areas }\end{array}$ & 0.487 & 0.187 & 0.009 & 1.627 \\
\hline & $\begin{array}{l}\text { Indicate signals when you } \\
\text { are changing lanes }\end{array}$ & 0.872 & 0.182 & 0.000 & 2.391 \\
\hline & $\begin{array}{l}\text { Overtaking a slow driver } \\
\text { from the left side }\end{array}$ & 0.579 & 0.149 & 0.000 & 1.785 \\
\hline \multirow{3}{*}{$\begin{array}{l}\text { Most of the } \\
\text { time }\end{array}$} & Mobile phone usage & 0.674 & 0.251 & 0.007 & 1.961 \\
\hline & $\begin{array}{l}\text { Taken an illegal U-turn at } \\
\text { restricted areas }\end{array}$ & 0.73 & 0.266 & 0.006 & 2.075 \\
\hline & $\begin{array}{l}\text { Indicate signals when you } \\
\text { are changing lanes }\end{array}$ & 0.954 & 0.258 & 0.000 & 2.596 \\
\hline \multirow[t]{6}{*}{ Always } & $\begin{array}{l}\text { Driving after alcohol } \\
\text { consumption }\end{array}$ & -0.987 & 0.495 & 0.046 & 0.373 \\
\hline & Mobile phone usage & 0.464 & 0.193 & 0.016 & 1.590 \\
\hline & $\begin{array}{l}\text { Taken an illegal U-turn at } \\
\text { restricted areas }\end{array}$ & 0.495 & 0.214 & 0.021 & 1.641 \\
\hline & $\begin{array}{l}\text { Indicate signals when you } \\
\text { are changing lanes }\end{array}$ & 1.08 & 0.200 & 0.000 & 2.946 \\
\hline & $\begin{array}{l}\text { Overtake vehicles in } \\
\text { restricted areas. (ex: double } \\
\text { lined road area and curvy } \\
\text { roads) }\end{array}$ & 0.568 & 0.272 & $\mathbf{0 . 0 3 7}$ & 1.764 \\
\hline & $\begin{array}{l}\text { Overtaking a slow driver } \\
\text { from the left side }\end{array}$ & 0.532 & 0.179 & 0.003 & 1.703 \\
\hline
\end{tabular}

From the $15 \beta$ coefficients, 14 of these values indicate how the participants who answered any Likert scale question favoured an option from the Likert scale, rather than selecting the reference option of the variable "Wearing seat belts even if it was for a short trip". From the 15 estimates, the same 14 criteria show that, for every unit increase of a participant answering any negative habitual question, the odds of a participant choosing any Likert scale option other than the reference option "never" 
kept increasing. The first set of results from Table 7 represents comparison between those who chose the option "occasionally" and those who opted "never". From those set of results, three parameters are statistically significant, having a significant value less than 0.05. Those are taking an illegal U-turn at restricted areas $(\beta=0.532, \mathrm{p}=$ $0.004)$, taking chance to try to speed and run a yellow light when it is about to change to $\operatorname{red}(\beta=0.341, p=0.042)$, and overtaking a slow driver from the left side $(\beta=0.49$, $\mathrm{p}=0.001$ ). Table 7 shows only the sets of comparisons which had a significant value less than 0.05 . The reference category is 'Never' in each variable.

The $\beta$ value of taking an illegal U-turn at restricted areas is 0.532 from the "occasionally" category and it is positive. This positive value suggests that those participants who answered the likert scale question "Taken an illegal U-turn at restricted areas" are more likely to select occasionally rather than selecting never of the variable "Wearing seat belts even if it was for a short trip". The odds ratio is given by the values of $\operatorname{Exp}(\beta)$. The odds ratio value of taken an illegal U-turn at restricted areas from the criteria "occasionally" is 1.703 . This means that for every one unit increase on a participant taken an illegal U-turn at restricted areas, the odds of a participant opting "occasionally" change by a factor of 1.703 . Since this value is greater than 1, it suggests that the odds are increasing. This is a further confirmation that as the participants answer the question on taking an illegal U-turn at restricted areas, they are more likely to answer "occasionally" relative to "never".

\section{CONCLUSIONS}

This study investigates the young drivers' habitual practices based on data collected through questionnaire forms with Likert scale questions. From this study the negative habitual practices of young drivers while driving are identified and the results proved how these habitual practices have an effect on a positive action of a young driver. The internal consistency among the Likert scaled items from Cronbach's alpha test is 0.705. This value is a good indication about the average correlation among the Likert scaled questions from the questionnaire. There are results of 45 available inter- item correlation values. The highest inter-item correlation value 0.467 was obtained for the pair; overtaking vehicles in restricted areas and taking chance to try to speed and run a yellow light when it is about to change to red.

Overall, the likelihood ratio test values from the multinomial logistic regression show that driving after alcohol consumption, mobile phone usage, taking an illegal U-turn at restricted areas, not indicating signals when you are changing lanes and overtaking a slow driver from the left side are the significant variables for seat belt not use of young drivers. That indicates these factors have an increased injury severity risk. These findings are in line with the previous studies conducted in other countries but overtaking slow vehicle from the illegal side was not identified as a young driver 
injury risk factor previously at authors' knowledge. This is a novel finding in the young driver safety research. A majority of young driver safety research was conducted in countries with homogenous traffic conditions which have different driver behaviours than Sri Lanka. Even in Sri Lanka, it is not legal to overtake a slow moving vehicle curbside, it can be dangerous and punishable. Under heterogeneous traffic condition in Sri Lanka, overtaking at curbside can be often seen in many urban areas in particular small vehicles like motorcycles and three-wheelers. This study identifies that young drivers overtaking slow moving vehicle from the illegal side as a negative habitual practice among young drivers and proper action should be taken to avoid this practice among young inexperienced drivers. Also, it is better to conduct a research study on this negative behaviour among all drivers because this seems as a critical issue in Sri Lanka. Driving after alcohol consumption, mobile phone usage, taking an illegal U-turn at restricted areas, and not indicating signals when young drivers are changing lanes are critical issues in the country as identified in this study.

Many countermeasures can be recommended to overcome these negative habitual practices. Several studies suggest that policy makers should develop programs targeting risky drivers focusing on education and public awareness [6]. The objectives of these programs are proposed as educating the public about the risk associated with negative habitual practices and reducing the percentage of those habitual practices among these risky drivers [6]. Some studies recommend increase the awareness people by educating them through media [16]. Some studies suggest design of new technologies related to vehicles as well as enforcement efforts. The habitual practices while driving highlight the importance of early intervention for improving road safety. In conclusion, there is always one or more habitual driving practices that has an effect on the other driving habits of a young driver.

\section{ACKNOWLEDGEMENT}

Authors would like to thank Ms. Malika Lakmali Guruge for helping the statistical analysis and for young drivers who have filled the questionnaire forms.

\section{REFERENCES}

[1] Solimana. A., Alhajyaseenb. W., Alfara. R., Alkaabia. I., 2018, Changes in Driving Behaviour Across Age Cohorts in an Arab Culture: the Case of State of Qatar, Procedia Computer Science, Volume 130, pp. 652-659.

[2] Klauer. S. G., Ehsani. J. P., McGehee. D. V., Manser.M., 2015, The Effect of Secondary Task Engagement on Adolescents' Driving Performance and Crash Risk, Journal of Adolescent Health, Volume 57, pp. 36-43. 
[3] Stephens. A. N., Nieuwesteeg. M., Smith. J. P., Fitzharris. M., 2017, Selfreported speed compliance and attitudes towards speeding in a representative sample of drivers in Australia, Accident Analysis \& Prevention, Volume 103, pp. 56-64.

[4] Horvath. C., Lewis. I., Watson. B., 2012, Peer passenger identity and passenger pressure on young drivers' speeding intentions, Transportation Research Part $F$, Volume 15, pp. 52-64.

[5] Ben-Ari. O. T., Skvirsky. V., Greenbury. T. J., Prato. C.G., 2018, Explaining risks behind the wheel - Comparing Israeli and Queensland young drivers, Transportation Research Part F, Volume 58, pp. 184-192.

[6] Shaabana. K., Gaweeshb. S., Ahmedb. M. M., 2018, Characteristics and mitigation strategies for cell phone use while driving among young drivers in Qatar, Journal of Transport \& Health, Volume 8, pp. 6-14.

[7] Alreesi. H., Freeman. J., Davey. J., Adawi. S. A., Maniri. A, A., 2018, Measuring risky driving behaviours among young drivers: Development of a scale for the Oman setting, Transportation Research Part F, Volume 55, pp. 78-89.

[8] Ben-Ari. O. T., Skvirsky. V., Greenbury. T. J., Prato. C.G., 2018, Explaining risks behind the wheel - Comparing Israeli and Queensland young drivers, Transportation Research Part F, Volume 58, pp. 184-192.

[9] Scott-Parker. B., Watson. B., King. M. J., Hyde. M. K., 2012, Young, Inexperienced, and on the Road: Do Novice Drivers Comply with Road Rules, Transportation Research Record, Volume 23, pp. 98-106

[10] Motor Traffic (Amendment) Act, 2009, The Government Publications Bureau, Volume 8, pp. 1-109.

[11] Department of motor traffic. 2016. Statistics. [ONLINE] Available at: http://www.motortraffic.gov.lk/web/index.php?option=com_content\&view=a rticle\&id $=84 \&$ Itemid $=115 \& l a n g=e n$. [Accessed 04 May 2020].

[12] Mathews. P., 2010. Sample Size Calculations: Practical Methods for Engineers and Scientists, Mathews Malnar and Bailey, Inc, Volume 1, pp. 1-325

[13] Tavakol. M., Dennick. R., 2011, Making sense of Cronbach's alpha, International Journal of Medical Education, Volume 2, pp. 53-55. 
[14] Favero. L. P., Belfiore. P., 2019, Binary and Multinomial Logistic Regression Models, Data Science for Business and Decision Making, Volume 14, pp. 539615 .

[15] Pallant. J., 2011, A step by step guide to data analysis using SPSS, SPSS Survival Manual, Volume 4, pp. 1- 345.

[16] Amarasingha, N. and Dissanayake, S., 2013, March. Modeling injury severity of young drivers using highway crash data from Kansas. In Journal of the transportation research forum Volume 5(1), pp. 5-22.

[17] Wang, Z., Zheng, Z. and Fleiter, J.J., 2016. Does family background impact driving attitudes and risky behaviours? An investigation on Chinese young drivers. Accident Analysis \& Prevention, 95, pp. 67-77. 